\title{
Recent Ethnodemographic Developments in the Central Part of the Alps-Adriatic Region: Slovenia, Croatia, Friuli-Venezia Giulia and Carinthia $^{1}$
}

\section{Damir JosIPovič, Ljubljana*}

with 2 figures and 7 tables in the text

\section{Content}

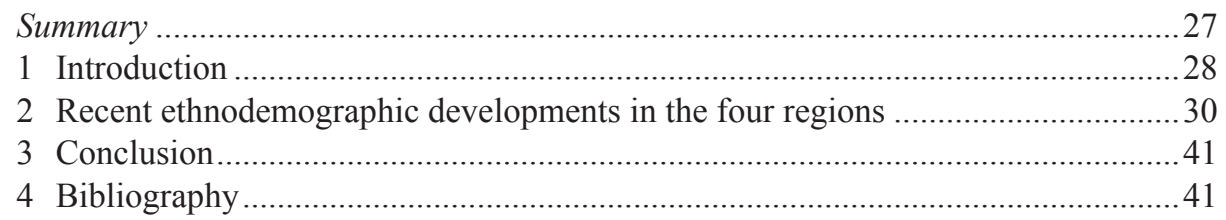

\section{Summary}

The Northern Adriatic space is a contact zone between several differing macroregions. As much as it is a transit area, state borders have changed several times. Its population shows a wide linguistic variety, but interethnic relations are close. The $20^{\text {th }}$ century left delimitations, which played and still play an important role for the ethnodemographic development of the region. Changes can systematically be traced back to the first modern census of 1857. In about one and a half century this area has gradually been transformed from a kaleidoscope of ethnic groups across the borders to a multitude of fluctuating and small ethnic identities.

$1 \quad$ This chapter is a result of the basic research project "Constitution of new national and ethnic identities in the Alps-Adria region with special regard to border areas and the city of Trieste, and to the "community-making" aspects of contemporary media (code: J6-0825)" lead by Dr Marija JURIČ PAHOR from the Institute for Ethnic Studies. (duration: 1.2.2008 - 30.1.2011) funded by the Slovenian Research Agency

* Damir Josipovič, PhD., Scientific Associate, Institute for Ethnic Studies, Ljubljana, Erjavčeva c. 26, SI-1000 Ljubljana, Slovenia; e-mail: damir.josipovic@guest.arnes.si 
Accordingly, available demographic data tend to concentrate on objectively measurable phenomena. Due to the gradual omitting of some traditionally observed population features like language or religion, national statistics leave little space for diachronic comparisons. But the data basis is good enough to confirm that the last few decades have witnessed completely new characteristics of demographic development.

This paper will firstly present a diachronic ethnodemographic analysis of the region from the times, when it was part of two monarchies until now, when it is split into four nation states. Secondly, the paper focuses on recent changes in ethnodemographic structure and on the new phenomenon of accelerated migration based on national statistics. In this respects it highlights the cases of Slovenia (especially its western region Littoral [Primorska/Littorale], Croatia (especially the regions of Istria [Istra/ Istria] and Kvarner/Quarnero), Italy (especially its northeasternmost region FriuliVenezia Giulia), and Austria (especially its southernmost province Carinthia [Kärnten/ Koroška]).

\section{Introduction}

Perhaps one of the scientifically most intriguing places in the entire Alpine-AdriaticDanubian region, the Northern Adriatic space is a unique contact zone between several differing macro-regions. The Northern Adriatic space in this context is understood as a geographically heterogeneous area, composed of land and sea and stretching from the Kvarner/Quarnero ${ }^{2}$ and the Istrian peninsula in the South to the alpine province of Carinthia [Kärnten/Koroška] in the North. This concept does not claim any kind of exclusivity for this space, but functions just as a frame for investigating into some typical aspects of contact and transition by placing them into a broader context.

It may be argued that such a view on the Northern Adriatic overlooks wide areas of the Adriatic space truly north-bound, especially those in the West of this imagined region. But it includes four macro-regions getting into contact here: the Adriatic basin, the Dinaric karst, the Alps and alpine piedmonts as well as the Po valley. The plethora of physical-geographic features with a linguistic and ethnic kaleidoscope made this region always being in motion (cf. MASSEY et al. 1998). Thus, we deal with a prominent investigative geographical laboratory.

As much as it is a transit area, state borders have changed several times and are shaped in an extraordinary way. They divide cultural landscapes - neglecting both the sense of place and the fates of populations - and do often not correspond to the "real

2 In this contribution all endonyms are presented, whether they are standardized and official or not, and separated by a slash. When an English exonym is used, the corresponding endonym(s) appear(s) in rectangular brackets with the first mentioning of the name. An endonym is by the United Nations in their most recent version of the Glossary defined as "name of a geographical feature in an official or well-established language occurring in that area where the feature is situated." (KADMON 2007, p. 2) 
world". However, the boundaries drawn half a century ago became gradually producers of space-related identities themselves (cf. PAAsI 1986). While superimposed at the beginning with the main goal of establishing an equilibrium between war-faring parties (cf. JONEs 1959) and disregarding central place systems and catchments, they were later accepted as the new "reality" and started shaping new central place systems.

Despite a wide linguistic variety in the region, close relations among populations exist. Before the advent of the national idea, in the times of supranational empires, people developed feelings of belonging to a ruler and his territory, and the cohesive power of a region was based on the strength of its leadership. After 1848, when nationalist movements emerged, the Northern Adriatic space became a contested terrain of antagonistic national ideas.

Being rather peripheries in the political and economic sense, the regions of the Northern Adriatic never developed centripetal forces based on a concept of their own. On the contrary, they welcomed the ruthless political plays of the $20^{\text {th }}$ century producing always new delimitations, which played, and still play an important role in the ethnodemographic development of the region.

Ethnodemographic changes may well be traced back to the first modern census of 1857. During about one and a half century this region has gradually turned from a mosaic of ethnic identities crossing borders into a multitude of individualized perceptions of identities. This was supported by national homogenization and the internally invasive nation state. The end of WWI brought a break-up of the Austro-Hungarian Empire and the creation of several new states. The Northern Adriatic, thus, became a contact area between Italy, Austria and the Kingdom of Serbs, Croats, and Slovenes, which later became the Kingdom of Yugoslavia. The whole area between the Adriatic Sea and the Alps represented a contested terrain for decades to come. It looks as if it will take about one hundred years from World War I to a reunification of the four neighbours (Austria, Croatia, Italy and Slovenia) by European integration.

It seems also that a globalizing economy and pertaining issues somehow veiled the local "ethnic" concerns. In the course of the past century the neighbouring states have slowly omitted statistical indicators which "measure" ethnic, linguistic and other cultural features of the population, although we still witness the importance ascribed to "ethnic" issues by the local population (e.g. treating the rights of national minorities). This ambivalence leads us to a confirmation of the "glocal" character of "things". Moreover, it implies that we have moved further in a sequence of time-space compression (cf. HaRVey 1989 p. 240, MASSEY 1993).

The question here is why certain countries omit or restrain the aforementioned indicators. We may, accordingly, argue that the available demographic data nowadays tend to concentrate around more objectively measurable phenomena. Furthermore, by gradually omitting the traditionally observed cultural population features like language, religion etc. national statistics raise methodological questions as well. They leave little space for diachronic comparisons. 
Besides, the last few decades have witnessed completely new aspects of demographic development. They may well be addressed as the "third demographic transition" (COLEMAN 2006). Former dualistic relationships are superimposed by high numbers of immigrants and migrant communities. Spatial relations tend to be more complicated and blurred. And the national statistical agencies are incapable of capturing the heavily accelerated population dynamics.

This paper will firstly present a diachronic ethnodemographic analysis of the region from the times, when it was part of two monarchies until now, when it is split into four nation states. Secondly, the paper focuses on recent changes in ethnodemographic structure and on the new phenomenon of accelerated migration based on national statistics. In this respects it highlights the cases of Slovenia (especially its western region Littoral [Primorska/Littorale], Croatia (especially the regions of Istria [Istra/ Istria] and Kvarner/Quarnero), Italy (especially its northeasternmost region FriuliVenezia Giulia), and Austria (especially its southernmost province Carinthia [Kärnten/ Koroška]).

\section{Recent ethnodemographic developments in the four regions}

To get a better imagination of ethnodemographic developments we have to refer in the first line to statistical data which are usually collected and published by national statistical agencies according to contemporary administrative divisions. Since the study focuses on recent developments, the censuses around 1991 and 2001 are most important. In 2011 only Croatia conducted a traditional census with questions for ethnic and religious affiliation, while Austria and Slovenia practiced a so-called "register census" lacking possibilities to ask for such characteristics. Italy had anyway also with traditional censuses not asked for such criteria.

In addition we used material from other sources, such as migration statistics, which are collected annually, and other demographic data on residents, migrant population, etc.

\subsection{Carinthia (Austria)}

Carinthia is situated in the South of modern Austria. Its geographical location contributes to its transit function. Although it is rather mountainous, it has in its centre a wide basin. The main communication corridors cross the province in NW-SE and NE-SW direction. The Karawanken/Karavanke mountain range forms a physical- 
geographical border towards Slovenia. After World War I the south-easternmost part of Carinthia around Gutenstein/Ravne was ceded to the Kingdom of Serbs, Croats, and Slovenes. Additionally, the municipality of Seeland/Jezersko was exchanged for the municipality of Weißenfels/Fusine/Bela Peč in the north-westernmost part of Carniola [Kranjska]. Curiously enough, the latter was not attached to the first Austrian republic, but to Italy.

Nowadays, Carinthia occupies an area of $9,536 \mathrm{~km}^{2}$ with about 560,000 inhabitants (see Table 1), which ranks it among less densely populated regions (58.5 inhabitants per $\left.\mathrm{km}^{2}\right)$.

Table 1: Carinthia's resident population in absolute figures and indices 1981-2011

\begin{tabular}{|c|r|r|}
\hline Year & Carinthia (Land) & Chain indices \\
\hline 1981 & 536,179 & $\ldots$ \\
\hline 1991 & 547,798 & 102.2 \\
\hline 2001 & 559,404 & 102.1 \\
\hline 2009 & 560,605 & 100.2 \\
\hline $2011^{*}$ & 558,085 & 99.6 \\
\hline
\end{tabular}

First quarter of 2011

Source: Statistik Austria 2011

Carinthia's traditional ethnodemographic characteristic is the dualism of two linguistic groups, German- and Slovene-speakers. Political debates frequently circle around this feature and the question of legal protection of the Slovene minority. ${ }^{3}$ Official numbers on the size of the Slovene group in the ethnic sense are not available. Only colloquial language data were officially collected and published up to and including the 2001 census. As regards ethnic affiliation we can only refer to estimates. ${ }^{4}$

The tradition of asking for the colloquial language with population censuses can - with the exception of the interwar period - be traced back to the censuses of the Habsburg Empire. But since then the function of Slovene as a colloquial language has changed dramatically. While in the former compact rural society Slovene was in predominantly Slovene villages indeed the language predominantly spoken also in the public sphere, this is not anymore so in the modern network society. Declaring to speak Slovene as the colloquial language has today rather the meaning of a political or ethnic confession (cf. Damuanić 2002, Šumi \& Josipovič 2008). Moreover, it is used to demonstrate the diminuation of Slovenes under German-speaking rule (e.g. KLEMENČIČ 1990, ZuPANČIČ 1999).

\footnotetext{
There is a harsh debate on Slovene place names in Carinthia. For a very instructive contribution on exo- and endonyms see JORDAN 2007

4 STEINICKE (2001) estimates the number of Carinthians with Slovene mother tongue at around 50,000 .
} 
The turn from a spatially compact rural cultural group into a network spread over most parts of Carinthia, also over typically non-Slovene speaking areas, can well be observed in Table 2 .

Table 2: Colloquial language by Carinthian Political Districts and resident population 2001

\begin{tabular}{|l|r|r|r|r|r|r|}
\hline & \multicolumn{2}{|c|}{ absolute number } & \multicolumn{5}{|c|}{ percentage (\%) } \\
\hline Political District & Slovene & "Windisch « & German & Slovene & "Windisch « & Other \\
\hline Carinthia & 14,010 & 556 & 92.39 & 2.50 & 0.10 & 5.01 \\
\hline Klagenfurt (city) & 1,722 & 8 & 89.43 & 1.91 & 0.01 & 8.65 \\
\hline Villach (city) & 382 & 6 & 90.62 & 0.66 & 0.01 & 8.70 \\
\hline Feldkirchen & 48 & 0 & 96.37 & 0.16 & 0.00 & 3.47 \\
\hline Hermagor & 147 & 38 & 96.62 & 0.74 & 0.19 & 2.44 \\
\hline $\begin{array}{l}\text { Klagenfurt } \\
\text { (surroundings) }\end{array}$ & 3,290 & 104 & 90.24 & 5.83 & 0.18 & 3.74 \\
\hline $\begin{array}{l}\text { Sankt Veit an der } \\
\text { Glan }\end{array}$ & 147 & 1 & 96.06 & 0.25 & 0.00 & 3.69 \\
\hline Spittal an der Drau & 289 & 0 & 95.29 & 0.35 & 0.00 & 4,36 \\
\hline $\begin{array}{l}\text { Villach } \\
\text { (surroundings) }\end{array}$ & 1,928 & 70 & 92.84 & 2.98 & 0.11 & 4.07 \\
\hline Völkermarkt & 5,920 & 329 & 82.48 & 13.59 & 0.76 & 3.18 \\
\hline Wolfsberg & 137 & 0 & 96.52 & 0.24 & 0.00 & 3.23 \\
\hline
\end{tabular}

Source: Statistik Austria, Census 2001

As we will see also in the other regions under investigation, the former linguistic and ethnic dualism is gradually replaced by a variety of ethnic groups. In the case of Carinthia, the Slovene-German antagonism is de facto outdated after the fall of the Iron Curtain and the Yugoslavian wars. This becomes obvious when we look at data by citizenship. Even if only Austrian citizens are regarded, the former divide into Germanspeakers and Slovene- (and "Windisch-")5 speakers is contested by an in many places higher share of other languages (see Table 3).

$5 \quad »$ Windisch « is in fact not a linguistic, but an ethnic category, although it is regarded by Austrian censuses as a linguistic classification. Those among Carinthian Slovenes regarding themselves as a part of the German, later Austrian nation used to classify themselves in this way. The word »windisch« as such is the former general German designation for all variants of Slavonic people - as opposed to »walisch« (in Carinthia) or »welsch« in other parts of the German-speaking lands for Romance people. 
Table 3: Colloquial language by Carinthian Political Districts and resident Austrian citizens 2001

\begin{tabular}{|l|r|r|r|r|r|r|}
\hline & \multicolumn{2}{|c|}{ absolute number } & \multicolumn{4}{|c|}{ percentage (\%) } \\
\hline \multicolumn{1}{|c|}{ Political District } & Slovene & "Windisch « & German & Slovene & "Windisch " & Other \\
\hline Carinthia & 12,554 & 555 & 96.44 & 2.38 & 0.11 & 1.08 \\
\hline Klagenfurt (city) & 1,308 & 8 & 96.15 & 1.58 & 0.01 & 2.26 \\
\hline Villach (city) & 198 & 6 & 98.00 & 0.38 & 0.01 & 1.61 \\
\hline Feldkirchen & 28 & 0 & 99.10 & 0.10 & 0.00 & 0.80 \\
\hline Hermagor & 122 & 37 & 98.81 & 0.65 & 0.20 & 0.35 \\
\hline $\begin{array}{l}\text { Klagenfurt } \\
\text { surroundings) }\end{array}$ & 3,115 & 104 & 92.98 & 5.80 & 0.19 & 1.03 \\
\hline $\begin{array}{l}\text { Sankt Veit an der } \\
\text { Glan }\end{array}$ & 66 & 1 & 99.14 & 0.12 & 0.00 & 0.74 \\
\hline Spittal an der Drau & 144 & 0 & 99.04 & 0.19 & 0.00 & 0.77 \\
\hline $\begin{array}{l}\text { Villach } \\
\text { (surroundings) }\end{array}$ & 1,758 & 70 & 96.13 & 2.87 & 0.11 & 0.89 \\
\hline Völkermarkt & 5,742 & 329 & 84,80 & 13.71 & 0.79 & 0.70 \\
\hline Wolfsberg & 73 & 0 & 99,36 & 0.13 & 0.00 & 0.50 \\
\hline
\end{tabular}

Source: Statistik Austria, Census 2001

While Slovene-speakers are much less then before concentrated on their former homelands, the Political Districts of Völkermarkt, Klagenfurt (surroundings) and Villach (surroundings), but dispersed all over Carinthia (and major Austrian cities outside Carinthia), they meet in many places a higher number of people with a third ethnic background, although foreign citizens are residing in Carinthia still well below the Austrian average (see Table 4).

Migrants in Austria make up for one ninth of the whole population. If the $3.3 \%$ share of naturalized population is added, Austria's population is at least at a share of $14 \%$ born outside the country. Carinthia has always been lagging behind the national average, except in the 1940s and 1950s, when it hosted a "repatriated" German-speaking population from former Yugoslavia and other eastern European countries. This situation has been accentuated after 1990, when especially Vienna [Wien] and other economically prosperous parts of Austria received a lot of migrants. Today, Carinthia hosts about $8.5 \%$ foreign-born population (see Table 4 ). Its overwhelming majority ( $60 \%$ or about 20,000 persons) descends from former Yugoslavia (Figure 1). 
Table 4: Foreign citizens in Carinthia and Austria 2011

\begin{tabular}{|c|c|c|c|}
\hline & & Austria & Carinthia \\
\hline \multirow{16}{*}{$\begin{array}{c}\text { Resident foreign } \\
\text { citizens }\end{array}$} & 1951 & 322,598 & 23,640 \\
\hline & $\%$ & 4.7 & 5.0 \\
\hline & 1961 & 102,159 & 7,752 \\
\hline & $\%$ & 1.4 & 1.6 \\
\hline & 1971 & 211,896 & 9,173 \\
\hline & $\%$ & 2.8 & 1.7 \\
\hline & 1981 & 291,448 & 8,156 \\
\hline & $\%$ & 3.9 & 1.5 \\
\hline & 1991 & 517,690 & 17,072 \\
\hline & $\%$ & 6.6 & 3.1 \\
\hline & 2001 & 710,926 & 32,071 \\
\hline & $\%$ & 8.9 & 5.7 \\
\hline & 2009 & 868,947 & 37,561 \\
\hline & $\%$ & 10.4 & 6.7 \\
\hline & 2010 & 895,144 & 38,407 \\
\hline & $\%$ & 10.7 & 6.9 \\
\hline \multirow{2}{*}{ Naturalizations } & $2000 / 2010$ & 277,414 & 8,644 \\
\hline & $\%$ & 3.3 & 1.5 \\
\hline
\end{tabular}

Source: Statistik Austria, 2011

Figure 1: Citizenship of foreign residents in Carinthia 2001

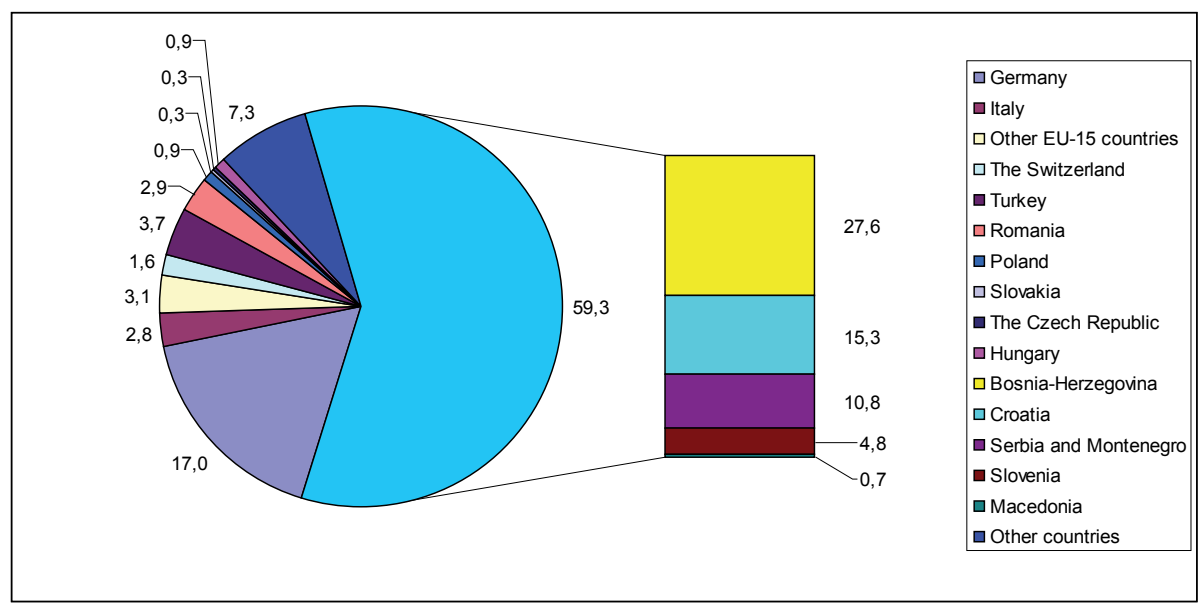

Source: Statistik Austria, Census 2001 


\subsection{Friuli-Venezia Giulia (Italy)}

Friuli-Venezia Giulia is one of Italy's five autonomous regions. It is located in the Northeast of the country and shares territorial borders with Slovenia and Austria. It occupies an area of 7,856 $\mathrm{km}^{2}$ with about 1,235,000 inhabitants (STAtistical OfFice OF ITALY 2011). With a population density of 156.7 inhabitants per $\mathrm{km}^{2}$, Friuli-Venezia Giulia is the most densely populated region in the central part of the Alps-Adriatic area. Administratively, it consists of the four provinces Udine/Udin, Pordenone/Pordenon, Trieste/Trst and Gorizia/Gurize/Gorica. Italy was the first of the four neighbours to avoid "ethnic" statistics. The last census collecting these data was conducted in 1921, i.e. on the eve of fascism. Later, only some estimates were made.

Traditional Slovene-speaking areas in Friuli-Venezia Giulia are Valcanale/Kanaltal around Tarvisio/Trbiž/Tarvis (formerly part of Carinthia), Slavia Veneta around Cividale del Friuli/Cividât/Čedad, the area of Gorizia/Gurize/Gorica and the province of Trieste/ Trst. In Slavia Veneta (Beneška Slovenija) according to the last official census of 1921 36,000 out of 52,000 residents in 15 municipalities were Slovenes. The vast majority of the rest were Friulians (a.o. Roglić 1946). Roglić (1946) estimates the Slovene-speaking population of Valcanale/Kanaltal at about 3,000 persons before WWII. Together with the provinces of Gorizia/Gurize/Gorica $(28,000)$ and Trieste/Trst $(62,000)$ the Slovenes roughly amounted to between 130,000 and 150,000 before WWII (RogLić 1946, STRANJ 1999). But the last Austrian census of 1910 and its revision in 1911 rather suggests that the number of Slovenes in the Trieste/Trst province was underestimated. The corrected number reached 80,000 (RogLić 1946) and was later supported by the results of the 1911 elections, according to which the number of Slovenes was 83,000 (STRANJ 1999, p. 299).

After the exodus (about 40,000) of Slovenes under fascism (STRAnj 1999), the post-war number of Slovenes was estimated at between 85,000 and 110,000 persons (StRAnj 1983). The lower estimation was, accordingly, confirmed by BufON (1992).

Apart from that, some official inquiries were carried out, mostly in connection with censuses. In spite of their official character, their only aim was to assess the ratio between Italian - and Slovene - speakers. They sheerly neglected the presence of other languages, first of all Friulian.

In 2001 Act No. 38 on the protection of the Slovene-speaking minority in FriuliVenezia Giulia was passed, but did not define the area of application concretely. So it took another couple of years to see its at least partial implementation. Only the Presidential Decree of 2007 defined 32 municipalities, on which the Act had to be applied. They included indeed almost all of the traditional Slovene-speaking area except four municipalities to which the Act was only partially applied.

This local and regional struggle for minority rights did, however, not pay attention to radical changes in population dynamics. Firstly, peripheral border areas were 
almost depopulated. The population of Drenchia/Dreka in the Udine/Udin province, e.g., decreased by $86 \%$, from 1,392 inhabitants in 1951 to 197 in 2001 . Secondly, a significant increase of international migration after the fall of the Iron Curtain led to larger shares of migrant population and to major changes in the demographic structure of the region.

Table 5: Migrant population in Friuli-Venezia Giulia by provinces 2003-2009

\begin{tabular}{|c|c|c|c|c|c|}
\hline & $\begin{array}{c}\text { Friuli-Venezia } \\
\text { Giulia }\end{array}$ & Udine & Gorizia & Trieste & Pordenone \\
\hline 2003 & 43,498 & 15,564 & 4,283 & 10,655 & 12,996 \\
\hline$\%$ & 3.7 & 3.0 & 3.1 & 4.4 & 4.5 \\
\hline 2004 & 51,889 & 18,654 & 5,165 & 11,432 & 16,638 \\
\hline$\%$ & 4.3 & 3.6 & 3.7 & 4.8 & 5.7 \\
\hline 2005 & 58,915 & 21,689 & 5,953 & 11,541 & 19,732 \\
\hline$\%$ & 4.9 & 4.1 & 4.2 & 4.8 & 6.6 \\
\hline 2006 & 65,185 & 24,166 & 6,600 & 12,406 & 22,013 \\
\hline$\%$ & 5.4 & 4.6 & 4.7 & 5.2 & 7.3 \\
\hline 2007 & 72,462 & 26,680 & 7,451 & 13,436 & 24,895 \\
\hline$\%$ & 6.0 & 5.0 & 5.3 & 5.7 & 8.2 \\
\hline 2008 & 83,306 & 31,313 & 8,360 & 14,852 & 28,781 \\
\hline$\%$ & 6.8 & 5.8 & 5.9 & 6.3 & 9.4 \\
\hline 2009 & 94,976 & 35,588 & 9,688 & 16,528 & 33,172 \\
\hline$\%$ & 7.7 & 6.6 & 6.8 & 7.0 & 10,6 \\
\hline
\end{tabular}

Source: Italian Statistical Office 2011

Table 5 shows that the period 2003-2009 was marked by an extensive increase of migrants. In total they doubled, while the most significant increase was registered in the Pordenone/Pordenon province, where their number eventually tripled. This province is the only one with a migrant population exceeding the $10 \%$ margin. This ranks it to the top of all four regions compared. Friuli-Venezia Giulia surpasses Carinthia's share of foreign residents $(7.7 \%$ vs. $6.9 \%)$, but its growth occurred mainly in the last decade, while it was more continuous in Carinthia.

The migrant population in Friuli-Venezia Giulia is far from homogeneous. By citizenship it is much more complex than Carinthia's. While the share of migrants from former Yugoslavia amounts to only 26\%, Romanians and Albanians are the largest groups contributing in total more than $30 \%$. The remaining $44 \%$ are heavily dispersed: $7 \%$ come from the former Communist countries Poland, Ukraine and Moldova, 5\% from Maghreb countries (Morocco and Tunisia), another 5\% from Ghana, 3\% each from India and the People's Republic of China (see Figure 2). 
It is significant that the notorious issue of Chinese immigration especially to the city of Trieste/Trst is far from being overwhelming. It comprises less than $3 \%$ of the whole migrant population of Friuli-Venezia Giulia, although Chinese citizens show a certain concentration on the Trieste/Trst province $(35 \%$ of the region's Chinese citizens).

Recent statistical and demographic data demonstrate that Friuli-Venezia Giulia is undergoing significant population shifts. On the one hand there are signs of social emancipation of Slovenes and Friulians, on the other migrants settle down in downtowns and suburbs replacing there the former population.

Figure 2: Citizenship of migrant population in Friuli-Venezia Giulia 2011

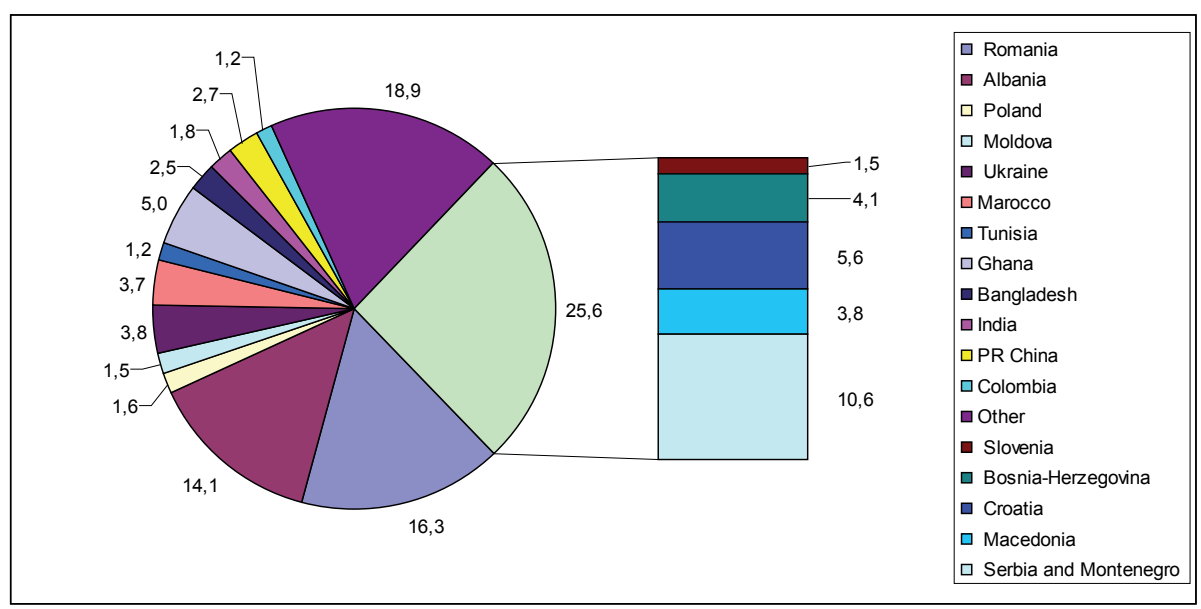

Source: Italian Statistical Office 2011

\subsection{Primorska/Littorale (Slovenia)}

Slovenia lacks administrative regions at the NUTS-3 level and is thus a rather centralized country (JosipoviČ 2009). It was also the only Yugoslavian republic that bordered as much as three other countries and only one other republic. Its geographical position between Italy, Austria, Hungary, Croatia and with an access to the Adriatic Sea ranks Slovenia among the physically and geopolitically most diverse countries compared to its size.

Nevertheless, even a relatively small country may have its periphery. Such a periphery is Primorska/Littorale. It is located in the far West of Slovenia bordering 
Table 6: Ethnic structure of Slovenia and Primorska/Littorale in 2002

\begin{tabular}{|c|c|c|c|c|c|c|c|c|}
\hline \multirow[b]{2}{*}{ Total } & \multirow{2}{*}{\begin{tabular}{|l|} 
Slovenia \\
$1,964,036$ \\
\end{tabular}} & \multirow{2}{*}{\begin{tabular}{|r|}
$\begin{array}{c}\text { Notranjsko- } \\
\text { kraška } \\
\text { Region }\end{array}$ \\
$\mathbf{5 0 , 2 4 3}$
\end{tabular}} & \multirow{2}{*}{$\begin{array}{r}\begin{array}{c}\text { Goriška } \\
\text { Region }\end{array} \\
118,511\end{array}$} & \multirow{2}{*}{$\begin{array}{c}\begin{array}{c}\text { Obalno- } \\
\text { kraška } \\
\text { Region }\end{array} \\
102,070\end{array}$} & \multicolumn{4}{|c|}{ percentage (\%) } \\
\hline & & & & & 100.00 & 100.00 & 100.00 & 100.00 \\
\hline $\begin{array}{l}\text { Ethnically declared - } \\
\text { Total }\end{array}$ & $1,766,982$ & 45,438 & 107,756 & 87,143 & 89.97 & 90.44 & 90.92 & 85.38 \\
\hline Slovenes & $1,631,363$ & 41,876 & 103,133 & 73,357 & 83.06 & 83.35 & 87.02 & 71.87 \\
\hline Italians & 2,258 & 19 & 100 & 1,866 & 0.11 & 0.04 & 0.08 & 1.83 \\
\hline Hungarians & 6,243 & 23 & 35 & 77 & 0.32 & 0.05 & 0.03 & 0.08 \\
\hline Roma & 3,246 & 4 & 14 & 6 & 0.17 & 0.01 & 0.01 & 0.01 \\
\hline Albanians & 6,186 & 225 & 476 & 538 & 0.31 & 0.45 & 0.40 & 0.53 \\
\hline Austrians & 181 & 1 & 1 & 8 & 0.01 & 0.00 & 0.00 & 0.01 \\
\hline Bosniaks & 21,542 & 554 & 667 & 2,174 & 1.10 & 1.10 & 0.56 & 2.13 \\
\hline Montenegrins & 2,667 & 26 & 80 & 169 & 0.14 & 0.05 & 0.07 & 0.17 \\
\hline Croats & 35,642 & 923 & 702 & 4,279 & 1.81 & 1.84 & 0.59 & 4.19 \\
\hline Macedonians & 3,972 & 80 & 295 & 397 & 0.20 & 0.16 & 0.25 & 0.39 \\
\hline Muslims & 10,467 & 237 & 365 & 676 & 0.53 & 0.47 & 0.31 & 0.66 \\
\hline Germans & 499 & 8 & 3 & 31 & 0.03 & 0.02 & 0.00 & 0.03 \\
\hline Serbs & 38,964 & 1,411 & 1,733 & 3,160 & 1.98 & 2.81 & 1.46 & 3.10 \\
\hline Other & 3,752 & 51 & 152 & 405 & 0.19 & 0.10 & 0.13 & 0.40 \\
\hline $\begin{array}{l}\text { Ethnically } \\
\text { undeclared - Total }\end{array}$ & 22,141 & 748 & 923 & 3,309 & 1.13 & 1.49 & 0.78 & 3.24 \\
\hline $\begin{array}{l}\text { Undeclared - } \\
\text { Yugoslavs }\end{array}$ & 527 & 10 & 24 & 64 & 0.03 & 0.02 & 0.02 & 0.06 \\
\hline $\begin{array}{l}\text { Undeclared - } \\
\text { Bosnians }\end{array}$ & 8,062 & 380 & 428 & 481 & 0.41 & 0.76 & 0.36 & 0.47 \\
\hline $\begin{array}{l}\text { Undeclared - } \\
\text { regional affiliation }\end{array}$ & 1,467 & 8 & 16 & 1,245 & 0.07 & 0.02 & 0.01 & 1.22 \\
\hline Undeclared - other & 12,085 & 350 & 455 & 1,519 & 0.62 & 0.70 & 0.38 & 1.49 \\
\hline $\begin{array}{l}\text { Did not want to } \\
\text { reply to the question } \\
\text { on ethnicity }\end{array}$ & 48,588 & 1,127 & 2,244 & 3,140 & 2.47 & 2.24 & 1.89 & 3.08 \\
\hline Unknown ethnicity & 126,325 & 2,930 & 7,588 & 8,478 & 6.43 & 5.83 & 6.40 & 8.31 \\
\hline
\end{tabular}

Source: Statistical Office of Republic of Slovenia, Census 2002 
Italy and Croatia and having access to the Adriatic Sea. Once it had also a common border with Carinthia. ${ }^{6}$ These features characterize it as a transitional region.

It is difficult to agglomerate data for the whole historical region of Primorska/ Littorale. So, for the purpose of a comparable analysis, we referred to the three westernmost statistical regions of Slovenia as constituting Primorska/Littorale, and data for these three regions are compared with the national average.

Since Slovenia (as well as Austria) did not conduct the 2011 census in a traditional manner by door-to-door inquiries, but as a register census, we have not anymore data on ethnic affiliation available to compare them with earlier situations. Some relatively recent data (from the 2002 census) on ethnic structure are nevertheless at our disposal (see Table 6).

The main differences between the 2002 census and the censuses 1981 and 1991 are due to methodological changes. While the 2002 census did not consider the socalled "gastarbeiter" population, both previous censuses did. Another issue is the new possibility not to answer the question for ethnicity. This resulted in a high share of the "did not want to reply" category. Together with the extremely high share of "unknown ethnic affiliation", this resulted in a reduced number of Slovenes. If, however, the nonresponse category is not included into the overall breakdown, the result is an even higher share of Slovenes (Josipovič 2007).

The 2002 census shows also reduced shares of other ethnic groups, especially of those from former Yugoslavia, which may hint at accelerated assimilation (Josipovič 2007). But the new migration trends in Slovenia show the opposite: The share of residents with foreign citizenship is increasing, but still well below $10 \%$.

As far as the Primorska/Littorale is concerned, the region undergoes the same processes, combining significantly higher shares of former Yugoslavian nations and the continued presence of a relatively small Italian constitutionally recognized minority (around 3,000 persons).

\subsection{Istria and Kvarner/Quarnero (Croatia)}

For Croatia as well as for its Northern Adriatic regions Istria and Kvarner/Quarnero much of the same is true as it was said about Slovenia. The two regions are located next to or not far from the Slovenian and Italian border.

Croatia, as Slovenia, has not a high share of ethnic groups other than the dominant nation. Among non-Croats ethnic groups from the former Yugoslavia prevail (see Table 7). The period after independence saw a radical decrease of Serbs due to the exodus from the former para-military Krajina. Still, Serbs remained above the national average in Kvarner/Quarnero. Italians and Slovenes remain concentrated on Istria and Kvarner/ Quarnero, where Italians (Venetians) were dominant in many places before World

\footnotetext{
6 When Valcanale/Kanaltal was a part of Carinthia until 1918.
} 
Table 7: Ethnic structure of Croatia, Istria and Kvarner/Quarnero in 2001

\begin{tabular}{|c|c|c|c|c|c|c|}
\hline \multirow[b]{2}{*}{ Total } & \multirow{2}{*}{\begin{tabular}{|l|} 
Croatia \\
$4,437,460$
\end{tabular}} & \multirow{2}{*}{\begin{tabular}{|c}
$\begin{array}{c}\text { Primorsko- } \\
\text { goranska } \\
\text { County }\end{array}$ \\
305,505
\end{tabular}} & \multirow{2}{*}{\begin{tabular}{|r|}
$\begin{array}{c}\text { Istarska } \\
\text { County }\end{array}$ \\
206,344 \\
\end{tabular}} & \multicolumn{3}{|c|}{ percentage (\%) } \\
\hline & & & & 100.00 & 100.00 & 100.00 \\
\hline Croats & $3,977,171$ & 258,438 & 148,328 & 89.63 & 84.59 & 71.88 \\
\hline Albanians & 15,082 & 2,063 & 2,032 & 0.34 & 0.68 & 0.98 \\
\hline Austrians & 247 & 36 & 26 & 0.01 & 0.01 & 0.01 \\
\hline Bosniaks & 20,755 & 3,021 & 3,077 & 0.47 & 0.99 & 1.49 \\
\hline Bulgarians & 331 & 33 & 33 & 0.01 & 0.01 & 0.02 \\
\hline Montenegrins & 4,926 & 643 & 732 & 0.11 & 0.21 & 0.35 \\
\hline Czechs & 10,510 & 145 & 103 & 0.24 & 0.05 & 0.05 \\
\hline Hungarians & 16,595 & 516 & 536 & 0.37 & 0.17 & 0.26 \\
\hline Macedonians & 4,270 & 489 & 454 & 0.10 & 0.16 & 0.22 \\
\hline Germans & 2,902 & 213 & 180 & 0.07 & 0.07 & 0.09 \\
\hline Poles & 567 & 68 & 35 & 0.01 & 0.02 & 0.02 \\
\hline Roma & 9,463 & 589 & 600 & 0.21 & 0.19 & 0.29 \\
\hline Romanians & 475 & 27 & 48 & 0.01 & 0.01 & 0.02 \\
\hline Russians & 906 & 88 & 45 & 0.02 & 0.03 & 0.02 \\
\hline Ruthenians & 2,337 & 61 & 31 & 0.05 & 0.02 & 0.02 \\
\hline Slovaks & 4,712 & 125 & 144 & 0.11 & 0.04 & 0.07 \\
\hline Slovenes & 13,173 & 2,883 & 2,020 & 0.30 & 0.94 & 0.98 \\
\hline Serbs & 201,631 & 15,005 & 6,613 & 4.54 & 4.91 & 3.20 \\
\hline Italians & 19,636 & 3,539 & 14,284 & 0.44 & 1.16 & 6.92 \\
\hline Turks & 300 & 67 & 57 & 0.01 & 0.02 & 0.03 \\
\hline Ukrainians & 1,977 & 87 & 78 & 0.04 & 0.03 & 0.04 \\
\hline Vlachs & 12 & 3 & 1 & 0.00 & 0.00 & 0.00 \\
\hline Jews & 576 & 27 & 17 & 0.01 & 0.01 & 0.01 \\
\hline Muslims & 19,677 & 3,402 & 3,831 & 0.44 & 1.11 & 1.86 \\
\hline Yugoslavs & 176 & 25 & 28 & 0.00 & 0.01 & 0.01 \\
\hline Other & 1,948 & 224 & 138 & 0.04 & 0.07 & 0.07 \\
\hline Ethnically undeclared & 89,130 & 11,914 & 21,978 & 2.01 & 3.90 & 10.65 \\
\hline $\begin{array}{l}\text { Regional affiliation } \\
\text { (of that) }\end{array}$ & 9,302 & 150 & 8,865 & 0.21 & 0.05 & 4.30 \\
\hline Unknown & 17,975 & 1,774 & 895 & 0.41 & 0.58 & 0.43 \\
\hline
\end{tabular}

Source: Statistical Office of Croatia, Census 2001 
War II. Very significant is also the high share (above 10\%) of ethnically non-declared population in Istria. The greater portion of it can be attributed to the so-called Istrians, who are not recognized as an ethnic group of their own (JosIPOVIČ \& KRŽIŠNIK-Bukić 2010, pp. 89f).

\section{Conclusion}

Although methodological constraints and a lack of comparable data prevented us from a full comparison, the collected material has the potential to support basic hypotheses. Thus, it was possible to show that in all four regions the former linguistic and ethnic duality was gradually replaced by a multitude of ethnic affiliations. In Carinthia, e.g., the former Slovene-German antagonism is de facto outdated. In Slovenia and Croatia traditional, stable ethnic affiliations have partly been replaced by multiple identities in a specific hierarchical order or varying in order according to circumstances. Very significant is also the fact that three of the four countries in question (The exception is Croatia.) do not ask for ethnic or linguistic affiliation in their censuses anymore, just for citizenship. This corresponds to the concept of the third demographic transition presuming a profound questioning of ethnic/national affiliation and the European nation state. This is also in line with a growing number of ethnically undeclared. The Slovenian Statistical Office consequently introduced various new ethnic affiliations (formerly referred to as regional).

\section{Bibliography}

Bufon M. (1992), Prostorska opredeljenost in narodna pripadnost: obmejna in etnično mešana območja v evropskih razvojnih silnicah: primer Slovencev v Furlaniji-Julijski krajini. Trieste, Založništvo tržaškega tiska.

Coleman D. (2006), Immigration and ethnic change in low fertility countries. A third demographic transition. In: Population and Development Review, 32, 3, pp. 401-446.

Damjanić D. (2002), Politizacija vprašanja o veroizpovedi pri popisu prebivalstva. Degree, Faculty of Social Sciences, Ljubljana.

Harvey D. (1989), The Condition of Postmodernity. Oxford, Blackwell Publishing.

Massey D. B. (1993), Power-geometry and a progressive sense of place. In: BIRD J. et al. (eds.), Mapping the Futures: Local Cultures, Global Change, pp. 59-69. London, Routledge.

Massey D.S. et al. (1998), Worlds in Motion - Understanding International Migration at the End of the Millennium. Oxford, Clarendon Press.

Italian Statistical Office (www.istat.it)

Jones S.B. (1959), Boundary concepts in the setting of place and time. In: Annals of the Association of American Geographers, 49, 3, pp. 241-255. 
Jordan P. (2007), Considerations on the definitions of "endonym" and "exonym". In: Jordan P., Orožen Adamič M., Woodman P. (eds.), Exonyms and the International Standardization of Geographical Names - Aproaches Towards the Resolution of an Apparent Contradiction, pp. 95-105. Wien - Berlin, LIT Verlag.

Josıpovič D. (2007), Spremembe etnične strukture prebivalstva v Sloveniji po letu 1991. In: Treatises and Documents, 53-54, pp. 98-115.

JosıPovič D. (2009), Razprava o odnosu center - periferija: peripanonski slovensko-hrvaški stik v sistemu širitve EU. In: Gosar A. (ed.), Development opportunities of Slovenian border regions, pp. 197-211. Annales, Koper.

JosIPOVIČ D., KRŽIŠNIK-BuKIĆ V. (2010), Slovensko-hrvaški obmejni prostor: etnične vzporednice med popisi prebivalstva po letu 1991. Ljubljana, Institute for Ethnic Studies.

Kadmon N. (ed.) (2007), Glossary of Terms for the Standardization of Geographical Names. ST/ ESA/STAT/SER.M/85/Add.1. New York, United Nations Secretariat.

KLEMENČIČ V. (1990), Metodologija uradnih popisov prebivalstva pripadnikov slovenske manjšine v Italiji, Avstriji in na Madžarskem. In: Narodne manjšine, Ljubljana, pp. 31-45.

PAASI A. (1986), Institutionalization of Regions. In: Fenia, pp. 1-46.

Roglić J. (1946), Le Recensement de 1910: ses méthodes et son application dans la Marche Julienne. Sušak.

Steinicke E. (2001), Potential for conflicts in areas of ethno-linguistic minorities of the Eastern Alps. In: Annales, Ser. hist. sociol., 11, 2 (26), pp. 259-266.

Stranj P. (1983), Demografsko gibanje v Furlaniji-Julijski krajini. In: Jadranski koledar, pp. $131-135$.

StRAnJ P. (1999), Slovensko prebivalstvo Furlanije-Julijske krajine v družbeni in zgodovinski perspektivi. Triest, SLORI.

State Office for Statistics of the Republic of Croatia (www.dzs.hr)

Statistical Office of the Republic of Slovenia (www.stat.si)

Statistics Austria (www.statistik.at)

Šumi I., Josipovič D. (2008), Avtohtonost in Romi: k ponovnemu premisleku načel manjšinske politike v Sloveniji. In: Two Homelands, 28, pp. 93-110.

Zupančıč J. (1999), Slovenci v Avstriji (= Geographica Slovenica, 32). Ljubljana. 